\title{
Muralf
}

INTERNACIONAL

\section{MACMILLAN, Margaret. A Primeira Guerra Mundial. São Paulo: Ed. Globo Livros, 2014, 724 p. ISBN 978.85.250.5790-7}

\section{TOMAZ ESPÓSITO NETO ${ }^{1}$}

Palavras-chave: Relações Internacionais, Política internacional, Primeira Grande Guerra Mundial.

Keywords: International Relations, International Politics, First World War.

Em 2014, a eclosão da Primeira Guerra Mundial (1914-1919), também conhecida como a Grande Guerra, completou cem anos. Esse conflito global ceifou a vida de milhões de pessoas, deixando outras dezenas de milhões feridas e/ou incapacitadas e gerando altíssimos custos políticos, sociais, econômicos e militares, sendo, portanto, responsável por marcar profundamente a sociedade moderna: a Grande Guerra acabou com a utopia liberal e a sociedade da Belle Époque; alterou as fronteiras políticas e redesenhou o mapa geopolítico mundial; grandes potências, como o Império Austro-Húngaro e o Otomano, desapareceram, enquanto "novas" ideologias globais, como o marxismo na Rússia, emergiram com muita força. Em suma, alterou as feições e a estrutura do sistema internacional.

Em função de sua importância, a Primeira Grande Guerra foi estudada por inúmeros e renomados historiadores, que publicaram grandes obras para explanar suas origens e consequências. Entre estas, destaca-se "A Primeira Guerra Mundial", da eminente historiadora canadense Margaret
Recebido em:

20 de Janeiro de 2015

Received on:

January 20, 2015

Aceito em:

12 de Março de 2015

Accepted on:

March 12, 2015

DOI: $10.12957 /$ rmi.2015.14560

${ }^{1}$ Doutor em Ciências Sociais pela Pontifícia Universidade Católica de São Paulo (PUC-SP). Professor Adjunto do Curso de Relações Internacionais da Faculdade de Direito da Universidade Federal da Grande Dourados (UFGD). Endereço para correspondência: Universidade Federal da Grande Dourados, Reitoria, Faculdade de Direito. Rua João Rosa Góes n 1761, Vila Progresso, CEP: 79825-070 - Dourados, MS - Brasil. E-mail: tomazesposito@ hotmail.com 
MacMillan. Fruto de um trabalho minucioso e dedicado baseado em fontes primárias (documentos oficiais, meios de comunicação da época, livros de memórias das autoridades do período, entre outros), essa obra foi traduzida e publicada em português pela editora Globo Livros, e é, certamente, um dos melhores trabalhos sobre o tema.

O texto é muito bem escrito; ao mesmo tempo simples, claro e didático, o que o torna interessante, acessível e compreensível a todos os públicos, tendo sido recebido com excelentes críticas por toda imprensa especializada e escolhido como um dos cem melhores livros de 2013 pelo jornal The New York Times, com toda justiça.

Além do prólogo e do epílogo, a obra divide-se em vinte capítulos, organizados em quatro partes bem delineadas. A primeira parte estende-se do prólogo ao capítulo 1, e é uma apresentação da estrutura políticoeconômica da Europa no início do século XX.

A segunda, do capítulo 2 ao capítulo 8, expõe a situação das grandes potências europeias (França, Alemanha, Inglaterra, Rússia e Império AustroHúngaro). A autora faz uma descrição pormenorizada das principais autoridades - de seus valores às suas intenções - e da influência das "forças profundas" (economia, demografia, geografia, mentalidade coletiva, entre outras) e das instituições nacionais como as forças armadas - no processo decisório de cada potência. Ademais, o texto analisa a atuação das grandes potências na formação da Tríplice Entente e da Tríplice Aliança através de todo o processo, das origens aos interesses.

A terceira parte, do capítulo 9 ao capítulo 12 , examina a opinião pública dessas potências mundiais, apresentando sucintamente um quadro das forças políticas antagônicas de cada uma delas, como o pacifismo e o militarismo, além das ideias e valores norteadores da $\mathrm{A}$ última parte, do capítulo 13 ao epílogo, discorre sobre os mais importantes acontecimentos políticos anteriores à irrupção da Primeira Guerra Mundial: a crise franco-germânica de Tânger (1905-1906); a anexação da Bósnia pelo Império Austro-Húngaro (1908-1909); a crise franco-germânica de Agadir (1911); as primeiras Guerras Balcânicas (1912-1913) e o assassinato do arquiduque austro-húngaro Francisco Ferdinando em Sarajevo (1914). Através desses fatos MacMillan identifica, com enorme competência, quais foram as forças e os agentes que levaram as principais potências mundiais à deflagração das hostilidades, 
Murralfy

bem como as tentativas fracassadas de se evitar a guerra, nos mostrando que, ainda nos dias atuais, podemos tirar lições da Primeira Guerra Mundial:

[...] Há muitas perguntas e outras tantas respostas. Talvez o máximo que possamos almejar seja compreender, tanto quanto nos for possível, aqueles indivíduos que tiveram de fazer as opções entre guerra e paz, suas forças e fraquezas, seus amores, ódios e tendências. Para isso, precisamos entender as suas premissas. Devemos lembrar, como lembram os que tomaram as decisões, o que aconteceu antes da crise de 1914 e as lições colhidas nas crises do Marrocos e da Bósnia, e no episódio das Guerras Balcânicas. O próprio sucesso da Europa em sobreviver àquelas crises anteriores gerou, por paradoxo, uma perigosa condescendência no verão de 1914 ,
Mural Internacional

V. $6 \mid$ N. 1

JAN-JUN 2015 quando os mesmos dirigentes acreditaram que mais uma vez uma solução surgiria nos últimos instantes e a paz seria mantida. Se quisermos, daqui do século XXI, apontar culpados, de duas falhas podemos acusar quem levou a Europa à guerra. Primeiro, de falta de imaginação ao não perceberem quanto o conflito seria destrutivo; e o segundo, falta de coragem para se impor aos que afirmavam não haver outra escolha que não fosse a guerra. Escolhas sempre há (MACMILLAN, 2014, p. 645).

Por todos os motivos supracitados recomendo vivamente a leitura de "A Primeira Guerra Mundial”, de Margaret MacMillan, uma bela obra que certamente nos ajudará a observar e repensar os erros e acertos do passado para projetar um novo futuro. 